\title{
DEVELOPMENT OF THE LATVIAN ENERGY SECTOR COMPETITIVENESS SYSTEM DYNAMIC MODEL
}

\author{
Valerijs Skribans ${ }^{1}$, Maris Balodis ${ }^{2}$ \\ ${ }^{I}$ Faculty of Engineering Economics and Management, Riga Technical University, \\ Kalnciema str. 6, Riga, LV1048, Latvia \\ ${ }^{2}$ Latvenergo AS, 12 Pulkveža Brieža Str., Riga, LV-1230, Latvia \\ E-mails: ${ }^{1}$ valerijs.skribans@rtu.lv (corresponding author); ${ }^{2}$ maris.balodis@latvenergo.lv
}

\begin{abstract}
One of the problems of the Latvian economy is related to the energy sector. In this sector the increasing competition is related to regional market expansion, building new transmission connection; fuels and electricity market price conjuncture significant change; energy efficiency requirements increasing, renewable energy requirements increasing and new market regulatory mechanisms. The system dynamics model can solve sector competitiveness problems. With the help of the developed model, it has been estimated that increase in total electricity consumption (around 10\%) can be expected in Latvia during the next 10 years. Decline in electricity loss and electricity imports is predicted. Increase of the capacity of production means and the amount of the produced energy is being forecasted.
\end{abstract}

Keywords: system dynamic, power supply, competitiveness, simulation, renewable energy sources, forecasting.

JEL Classification: C53; L94; O20; Q40.

\section{Introduction}

Many of the optimization methods used for making long-term forecasts of the Latvian electricity supply are based on voluminous data analysis, detailed assessment of consumption and delivery structures for various scenarios. Updating of complex models is time-consuming. Often the obtained results have not provided the desired results. They have been usable for relatively short periods of time because changes in the influencing factors and economic situation have overtaken the corrections made within evaluations. It creates the need to simultaneously apply system dynamics methods, of less details and accuracy, however it allows performing evaluation of optimization of development scenarios. Especially in cases where decisions on strategic projects must be made within tight deadlines, which significantly affects several economic sectors and electricity supply services.

Modelling of energetic processes and systems is a task that has undergone a huge growth process during the last years. The total number of available energetic models has increased enormously, resulting in vastly differing energetic models; thus, a question arises concerning which of the models is more appropriate for a specific goal or situation.

The aim of this research is to create system dynamic model taking into account interdepend- ance of cogeneration plants and implementation of renewable resources in electricity and heat supply.

Literature contains a wide classification of models (Timilsina 2011), by their type of use (Ozoliņa, Počs 2013), methods (Herbst et al. 2012), application at a geographical scale (regional, state) (Kavrakoğlu 1980; Schulz, Stehfest 1984), regional and state specifics (Groscurth, Kümmel 1989). It is possible to group the models as ascending or engineering models, and descending or macroeconomic models (van Beeck 1999; Grubb et al. 1993). They are based on various groups of methods, including cost-output tables (Nathani 2006), models of agents and multi-agents (Kremers 2013), stochastic models (Wallace, Fleten 2003), determined (Zeng et al. 2011), fuzzy logic models (Kagan, Adams 1994; Sadeghi, Hosseini 2006), models of interval mathematical programming (Huang et al. 1995; Yeh 1995). Most often hybrid systems are applied in forecasts of energy demand and offer in 29 European countries (Schade et al. 2009). In recently developed models increasing amount of attention is devoted to reducing emissions and use of renewable energy resources (Martins et al. 1996; Kélouwani et al. 2005).

Existing engineering models evaluate energy supply systems mainly through analysing information on costs and prices. Thereby, results of such models depend on the market model and 
regulating structures within each market. A large number of these models are described in literature, and often the provided insight into their applicability is of less volume than that into their solving methods. Therefore, efficiency of some of these researches for infrastructure investors and policy makers is not always obvious.

Macroeconomic energy models attempt to show economy in general - at a state or regional level. They contain an overall technological description and do not provide sufficient indications regarding the possibilities of technological progress.

Methods of Fuzzy Mathematical Programming (FMP) can be applied for determining fuzzy functions of participation, which can be used within a system of optimization (mainly it applies to FPP - Fuzzy Parameter Programming). These methods have a characteristic certain subjectivity. Secondly, both FFP (Fuzzy Flexible Programming), and FPP solution procedure can lead to complex processes. Thirdly, majority of FPP methods can result in an unsolved result due to increased calculation volumes.

Stochastic mathematical programming methods have uncertainties that could be easily processed and expressed as probability density functions. However they also have several drawbacks. First of all, it is difficult to create a distribution of relevant parameters for practical problems. Secondly, most of these methods are mainly offered based on assumptions that distribution of relevant parameters is determined. It can lead to system non-resolution when parameters are dynamic and related to intense variations. Thirdly, requirements of stochastic mathematical programming calculations are relatively high, especially regarding large-scale practical tasks.

Methods based on Interval Mathematical Programing (IMP) can easily solve uncertainties that are impossible to express in the form of intervals. However, these methods have drawbacks. Firstly, because majority of parameters in IMP programming are expressed in the form of intervals without information on distribution, it can lead to disproportionate simplification of real problems if any of the parameters could be expressed with the help of a probability. If interval ranges are wide, the model of optimization could become irresolvable.

In addition to theoretical literature the following practically-applied models have been evaluated: EFOM-ENV (Energy-Environmental Flow Optimisation Model), ENPEP (Energy and Power Evaluation Program), LEAP (Long-range Energy Alternatives Planning), MARKAL-MACRO,
TIMES (The Integrated MARKAL-EFOM System), MESAP (Modulare Energiesysemanalyse und Planung), MESSAGE-III (Model for Energy Supply Strategy Alternatives and their General Environmental), RETscreen (Renewable Energy Technology), MERGE (A Model for Evaluating the Regional and Global Effects of GHG Reduction Policies). DIME (Dispatch and Investment Model for Electricity markets in Europe), E3ME (E3: Energy-Environment-Economy model), NEMS (National Energy Modelling System), MAED (Model for Analysis of Energy Demand), WASP, RESGEN (The Regional Energy Scenario Generator), SAGE (System for the Analysis of Global Energy Markets).

Models practically applied in Latvia are the following: WASP (Wien Automatic System Planning Package 2001), MESSAGE (Schrattenholzer 1981) UPLAN-E (Latvenergo 1999), and MARKAL-LV (Reķis 2014).

WASP allowed planning of the more rational development of power plants through applying the least-cost method. However, the drawback of such model was that it was not designed for the analysis of cogeneration plants; therefore operation of combined heat and power plants (CHPs) was described in a very simplified manner. By using this programme modelling of Latvian electricity demand coverage was performed. It provided the possibility of constructing a new natural gas power plant and/or coal power plant in the Kurzeme Region (Liepaja), fully reconstructing the existing Riga CHPs.

MESSAGE software was used in the modelling of the energy sector and for the analysis of scenarios. This software enables: complex modelling of processes of primary energy resources generation, processing and transporting; complex modelling of import and export of primary energy resources; complex modelling of transmission and distribution of electrical energy and thermal energy; complex modelling of end end-user consumption of energy and energy resources.

The aim of MESSAGE project was to develop possible development scenarios of the energetic sector of the Baltic countries for period up to year 2030. The project included representatives from the International Atomic Energy Agency, NATO, Estonia, Latvia, and Lithuania.

The model of each country included the optimization of the most characteristic elements of energetics infrastructure. In Estonia they were: extraction and export of oil shale and shale oil; generation of electrical energy, mainly in the Narva oil shale power plants; centralized heating sup- 
ply systems in Tallinn, Narva and other cities. In Latvia they were: import and export of petroleum products; generation of electrical energy at Daugava HES cascade and Riga combined heat and power plants; centralized heating supply systems in Riga and other cities. In Lithuania they were: extraction, processing, import, and export of petroleum products; generation of electrical energy at the Ignalina NPP; condensing of natural gas/fuel oil at the electrical power plant and combined heat and power plants; import of nuclear fuel; hydro accumulation power plant; centralized heating supply systems in Vilnius, Kaunas, Klaipeda, and other cities. Besides, import of natural gas and coal, extraction of peat and wood, production of peat briquettes and biogas, transport and distribution of fuels, conditions of electricity transmission, enduser consumption of energy and fuels in industry, agriculture, transport, commercial sector, and that of population.

The modelling results showed that after year 2015 more attention has to be devoted to $\mathrm{CO}_{2}$, and especially $\mathrm{NO}_{\mathrm{x}}$ emissions.

With the help of program "Uplan-E" a plant that generates the least costs for the Baltic region was calculated. Specialists from Eesti Energijas, Lietuvos Energijas, DC Baltija, and Latvenergo participated in the development of this plan.

The used Uplan-E program correctly optimizes only condensation power plants. In order to optimize TEPs, which play a key role in Latvia, the given version of Uplan had to be subjected to various artificial assumptions. These assumptions decreased the accuracy of calculations.

A modification of the model was developed for prevention. The principle idea of an improved cogeneration model was to find a combination of generation equipment that would ensure sufficient safety and lower costs for the supply of thermal energy and electrical energy. The cogeneration model had to compare generation of thermal energy and electrical energy in cogeneration power plants through producing them separately (thermal energy - at boiler houses, electrical energy - at electrical power plants).

With the use of MARKAL-LV model the primary types of Latvian resources consumption were determined for the period up to year 2030; transformation sector was characterized; cost analysis was performed in the modelled scenarios.

An important next step in the development of a system dynamics model of the Latvian energy sector was made in year 2009 (Skribans 2010). The key role of the model was to forecast energy consumption in separate groups by consumers and by groups of energy resources, as well as to assess the impact of energy sector on the environment. This project still affects the Latvian state policy in the field of energetics (Tuvikene et al. 2015), as well as in others fields (Zeps, Ribickis 2014; Lapina 2015). However, at the same time new circumstances appeared which determine the model application actuality in Latvia. The system dynamics model of the Latvian energy sector is designed for flexible and operative checking of scenarios when decisions are made on the realization of strategic and large-scale projects, for which the long-term impact on costs of electricity and thermal energy supply are important. It allows evaluating the competitiveness and mutual impact of these energy sub-sectors, as well as the impact on regional trading aspects. The model follows the mutual impact of indicators of the implementation of renewable energy resources, energy efficiency and national self-sufficiency. The systemdunamic method supplements other methods (Hudenko, Počs 2015).

\section{The method}

This section reflects the model developed in the research, describes the applied method, as well as the assumptions of the research and model. The structure of the model is shown in Figure 1.

The key role in the model (Fig. 1) is given to the electricity consumption unit. Primarily, companies of the energy sector have to provide Latvian consumers with the required energy and, secondary - they have to compete in international markets. The electricity consumption unit forecasts energy consumption taking into consideration several development scenarios of the economic sector.

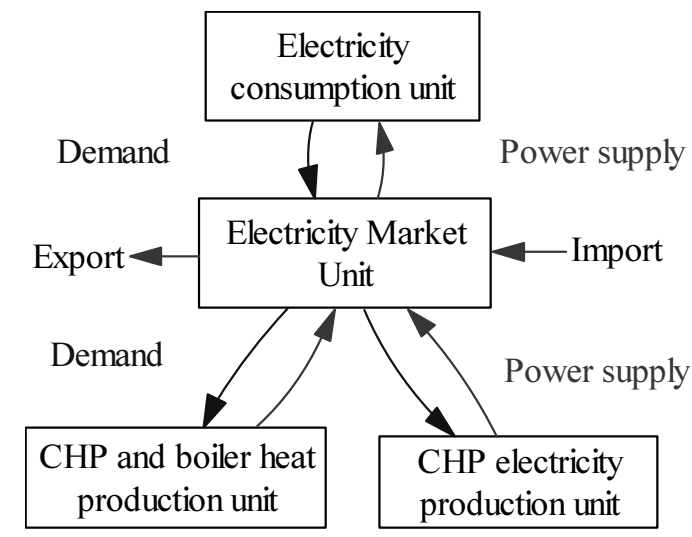

Fig. 1. Competitiveness system dynamics model of the Latvian energy sector companies (Source: Authors)

Electricity market unit combines electricity demand and offer, evaluates the competitiveness of energy sub-sectors in the international market. 
The group of production units consists of the CHP and boiler house thermal energy production unit and CHP electrical energy production unit.

\subsection{Electricity consumption unit}

Electricity consumption unit performs forecasts of electrical energy in the most important groups: agriculture, industry, services, transport, and population.

Consumption of electricity in sectors is forecasted based on the anticipated output volume (for example, for production). Consumption of electricity is forecasted in accordance with the anticipated number of consumers (for example, trolleybuses in transport). Consumption of electricity of households is connected with the driving force of economics - number of employees.

Calculations of electricity consumption of sectors are based on regression coefficients that connect output (number of elements of impact) and consumption of energy. Thereby, the developed model includes not only system dynamics, but also elements of other methods. Accordingly, a model of mixed type was developed that is one the novelty elements of the research.

By adding together consumption by sector and electricity consumption of the population, end-user consumption of electricity is calculated.

\subsection{CHP electricity production unit}

The total simplified schematics of the CHP electricity production unit is shown in Figure 2.

It can be seen in Figure 2 that volume of demand and price of energy is at the core of CHP electricity production. Volume of demand can be limited by technical capabilities, i.e., with production capacity etc.

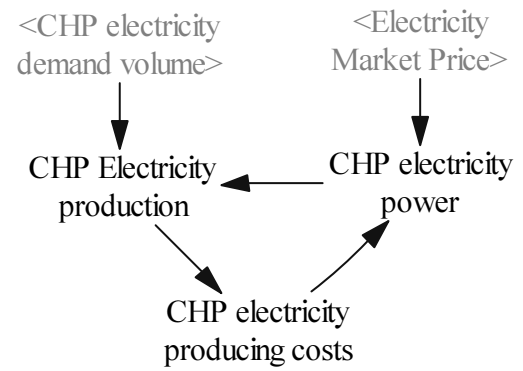

Fig. 2. Total simplified schematics of the CHP electricity production unit (Source: Authors)

Production of electricity is equal to the value resulting from the CHP capacity and volume of demand.
Production costs, interacting with electricity market price throughout the process of production, determine the development of companies (i.e., increase of capacity), as well as loss of competitiveness in conditions of a crisis.

The complex algorithm applied for the calculation of CHP electricity production costs is show in Figure 3.

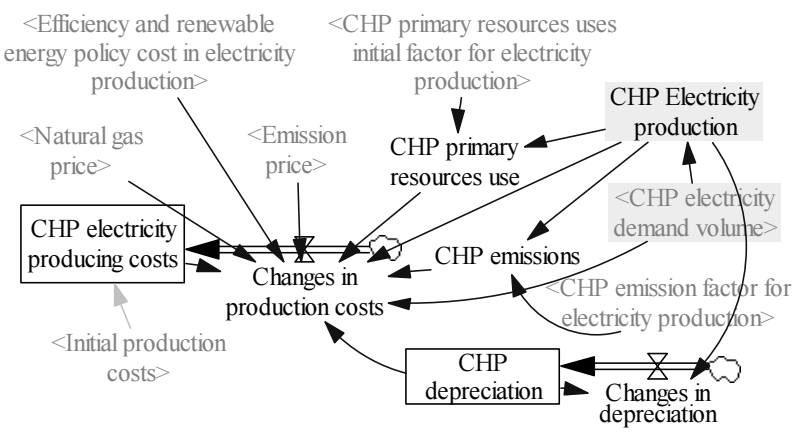

Fig. 3. Summary schematics of the algorithm applied for the calculation of CHP electricity production costs (Source: Authors)

The elements shown in Figure 3 (CHP electricity volume of demand and CHP electricity production) serve as a starting point of the algorithm. The algorithm reflects many factors outside the model, such as, price of emissions, price of natural gas, technical and technological coefficients.

Production process is connected with consumption of resources, creation of emissions and certain costs.

Consumption of primary resources of CHP for a short and temporary period can be calculated by dividing the output volume by the coefficient of consumption of technologic energy resources necessary for production output. In its turn, consumption of primary resources for a medium and longterm period could decrease. It can be shown as an increase of efficiency.

Both the CHP emissions volume and the CHP consumption of primary resource affect the CHP production costs.

All production costs are summed up in calculating costs: emission and natural gas costs; depreciation and NPP policy costs for electricity production. The summary costs are divided by CHP electricity production volume, thus obtaining costs per unit of production.

The algorithm shown in Figure 4 was applied for calculating CHP electrical capacity.

Potential profit of CHP electricity is calculated from electricity market price and potential CHP electricity price. 


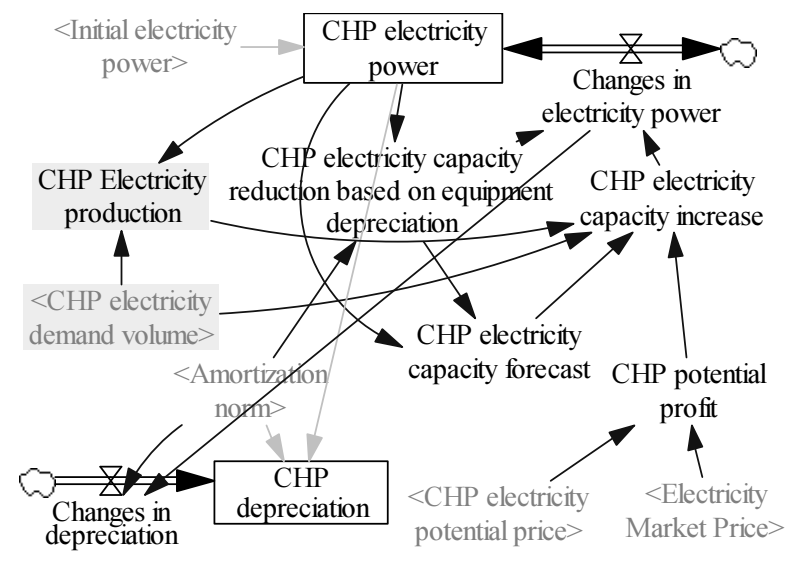

Fig. 4. Summary schematics of the CHP electrical capacity calculation algorithm (Source: Authors)

The model follows a pattern: potential profit is always positive. It shows that no one will produce energy with losses over a long period of time.

Potential CHP profit is a determining factor in CHP development and its capacity increase.

Electrical energy capacity increase is determined by two factors - CHP profit and the need for means of production (capacity). If the profit of the companies of the sector is higher than the depreciation of the means of production, then the whole profit is reinvested. In circumstances when companies operate without profit or with losses, means of production need to be renewed. In such cases electricity capacity increase is calculated as the positive (higher than zero) difference between the demanded volume and forecasted electrical energy capacity.

Throughout the development of the model particular attention was paid to determining the volume of reinvestments because the volume of reinvestments does not always coincide with profit - it could be both lower, and higher. A lower volume could be due to extraction of profit from the sector, whereas a higher volume could be due to the specifics of the sector - huge capital investments in fixed assets. It could be that investments do not pay off within 10 , 15 or even more years. It could significantly affect the development of the sector within a short, medium and prolonged period of time. Series of simulations were carried out with various algorithms of profit reinvestment, thus it was practically determined that the mentioned algorithm better simulates development of the sector.

Simultaneously with the increase in capacity it is possible for capacity to decrease due to equipment depreciation. CHP decrease in electricity capacity due to depreciation of equipment depends on the existing capacity and depreciation (or amortization) norm.

Figure 4 shows changes in capacity happening simultaneously with changes in the volume of depreciation.

The depreciation indicator was applied in the algorithm for calculating electrical energy production costs.

By combining the calculation algorithm of electrical energy production costs with the calculation algorithm of electrical energy capacity, the electrical energy production unit was formed. Its summary schematics are shown in Figure 5.

After introducing the CHP electrical energy production unit we will move on to the electrical energy market unit.

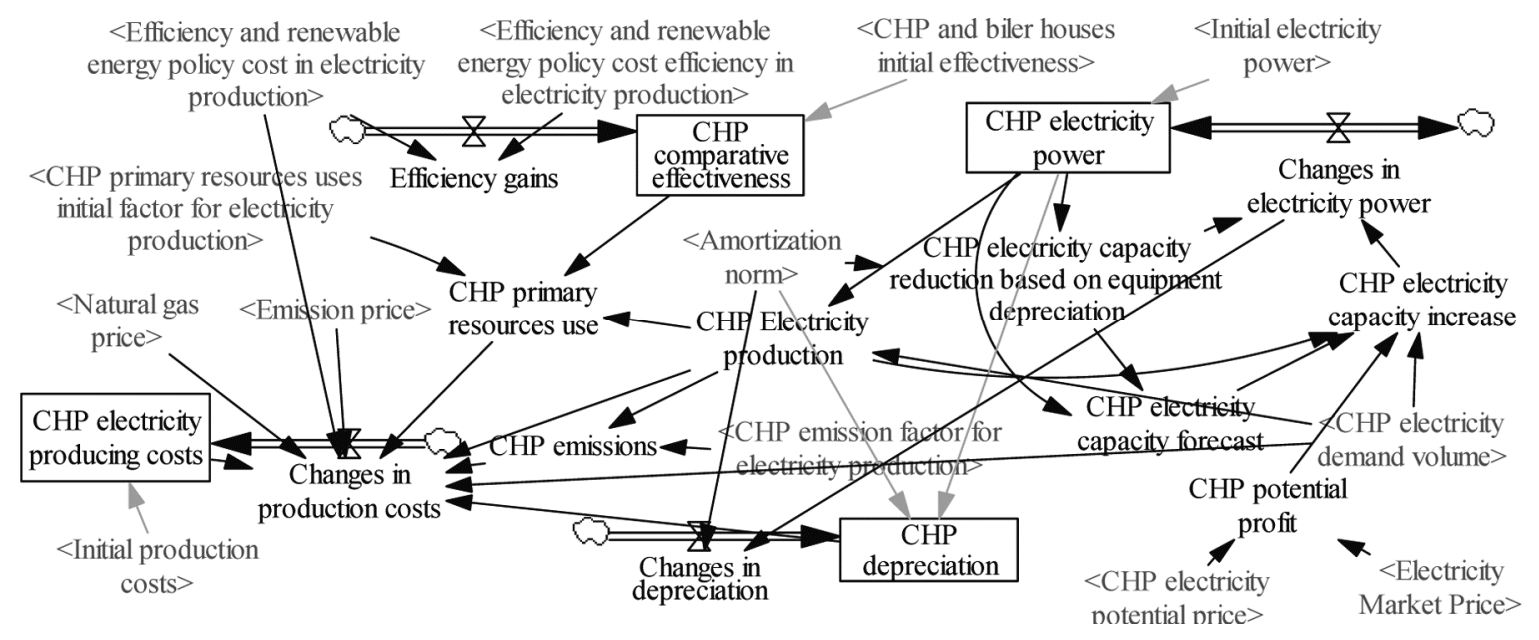

Fig. 5. CHP production unit (Source: Authors) 


\subsection{Electrical energy market unit}

The essence of the electrical energy market unit is described in a simply way in Figure 6.

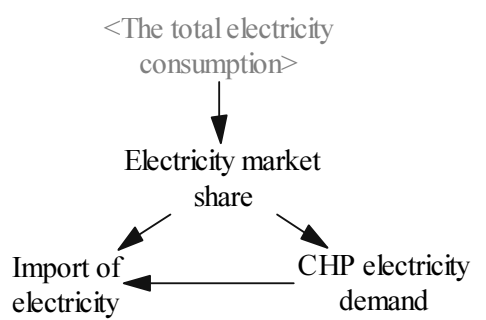

Fig. 6. Summary schematics of the electrical energy market unit (Source: Authors)

The electrical energy market unit is based on the total consumption of electricity, which is calculated within the electricity consumption unit. Production of electrical energy that is not connected with the market share (mandatory procurement components) is subtracted from the total consumption. The actual market situation is such that in Latvia electrical energy is produced only if its production costs are lower than the market prices. The rest of the electrical energy is imported. Thereby, the volume of electrical energy generated in Latvia and the volume difference of import between the production and demand is calculated.

It is important to note that in Latvia, with the exception of the previously mentioned mandatory procurement components, one more relevant type of electrical energy production exists that affects the market - production of electrical energy in CHPs. The modelling of their operation can be guided by the highest level of abstraction - production of electrical energy in CHPs does not depend on the model data or the economic situation. In fact, it depends only on weather conditions, which cannot be forecasted within the model. Accordingly, it is assumed in the model that production of electrical energy in CHPs is a constant indicator and that its volume does not affect the volumes of CHP electrical energy demand or import regarding competitiveness. Thereby, production of electrical energy in CHPs remains outside market competition in the model. Such an assumption is justified because CHP electrical energy prices are always lower than those of CHP or prices of import electrical energy.

Accordingly, the electrical energy market unit shows the interaction between CHP production volume and import volume.

Generation of CHP electrical energy depends on electrical energy demand (electrical energy market share) and the market price at a specific moment (reflected by the price difference impact coefficient).

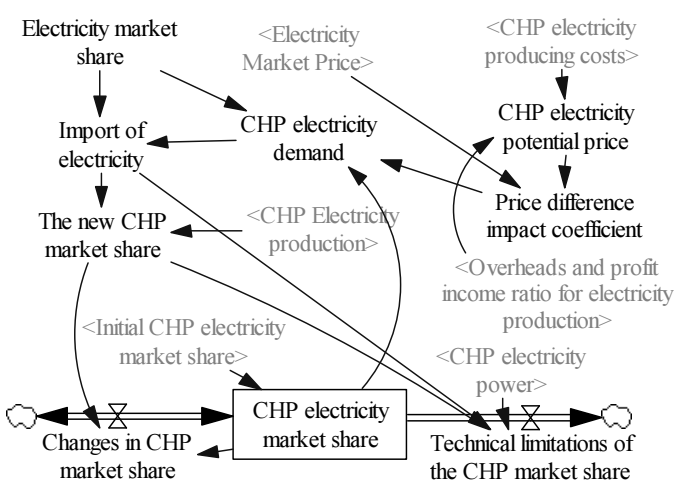

Fig. 7. Electrical energy market unit (Source: Authors)

Two principles are followed when calculating the price difference impact coefficient. This coefficient is always higher than one. It means that, despite adverse market conditions, low prices, the market share of electrical energy produced in Latvia will not decrease. This justification is connected with the application of the effective mode in the operative management of Latvian CHPs. The higher the market price and the CHP potential price difference, the higher the coefficient becomes, and, accordingly, demand for CHP electrical energy will also be higher.

CHP electrical energy potential price is based on CHP electrical energy production costs (from the electrical energy production unit) and the income ratio. Currently the market situation is such that the income ratio is close to zero, i.e., production of electrical energy covers only the variable costs.

Based on import volumes and the production (actual) of CHP electrical energy, the new market share of CHPs is calculated.

Indicator "CHP electricity market share" shows the actual CHP market share of the current period, by following both the demand, and production volumes. This indicator does not take part in determining the CHP demand of the current period; however it will affect the demand of the next period.

CHP technical limitations decrease the CHP market share if unplanned changes in electrical energy import take place. As a whole, the model assumptions are based on the practical situation in Latvia. After model description, the next section shows its application.

\section{Research results and discussion}

\subsection{Forecasts on market sector modelling}

The first modelling indicator to be analysed is the consumption of electrical energy, which is shown in Table 1. 
Table 1. Electrical energy consumption forecast, GWh (Source: Author)

\begin{tabular}{l|r|r|r|r|r}
\hline & $\mathbf{2 0 1 7}$ & $\mathbf{2 0 1 9}$ & $\mathbf{2 0 2 1}$ & $\mathbf{2 0 2 3}$ & $\mathbf{2 0 2 5}$ \\
\hline Total consumption & $\mathbf{7 2 6 6}$ & $\mathbf{7 4 3 7}$ & $\mathbf{7 6 3 4}$ & $\mathbf{7 8 3 9}$ & $\mathbf{8 0 5 3}$ \\
\hline Losses & 428 & 420 & 432 & 443 & 455 \\
\hline $\begin{array}{l}\text { End-user con- } \\
\text { sumption }\end{array}$ & $\mathbf{6 8 3 7}$ & $\mathbf{7 0 1 6}$ & $\mathbf{7 2 0 2}$ & $\mathbf{7 3 9 6}$ & $\mathbf{7 5 9 8}$ \\
\hline .households & 1781 & 1803 & 1826 & 1849 & 1871 \\
\hline .industry & 1631 & 1662 & 1695 & 1730 & 1768 \\
\hline .agriculture & 172 & 175 & 179 & 183 & 188 \\
\hline .transport sector & 119 & 120 & 122 & 123 & 125 \\
\hline ..road transport & 59 & 60 & 62 & 63 & 65 \\
\hline ..piping transport & 20 & 20 & 20 & 20 & 20 \\
\hline .railway transport & 40 & 40 & 40 & 40 & 40 \\
\hline .construction & 82 & 84 & 87 & 90 & 93 \\
\hline other sectors & 3053 & 3171 & 3293 & 3420 & 3552 \\
\hline & & & &
\end{tabular}

A slight increase in electrical energy consumption is forecasted in all sectors. Energy losses will decrease till year 2018 due to increase in efficiency; however, later they will increase in accordance with the overall tendencies of electrical energy consumption. The effect of the energy consumption increase could be more visible than that of the efficiency increase after year 2018.

It is important to know, whether the national companies-produces would be competitive in conditions of increased electrical energy demand to the same extent as they are currently, compared to foreign companies. The data of market sector modelling help to answer this question. They are shown in Table 2.

Table 2. Forecast of electrical energy market in the base scenario, GWh (Source: Authors)

\begin{tabular}{l|l|l|l|l|l}
\hline & $\mathbf{2 0 1 7}$ & $\mathbf{2 0 1 9}$ & $\mathbf{2 0 2 1}$ & $\mathbf{2 0 2 3}$ & $\mathbf{2 0 2 5}$ \\
\hline Total consumption & $\mathbf{7 2 6 7}$ & $\mathbf{7 4 3 7}$ & $\mathbf{7 6 3 4}$ & $\mathbf{7 8 4 0}$ & $\mathbf{8 0 5 4}$ \\
\hline $\begin{array}{l}\text { Market share of } \\
\text { electrical energy } \\
\text { consumption }\end{array}$ & 5981 & 6151 & 6348 & 6554 & 6768 \\
\hline $\begin{array}{l}\text { Market share of } \\
\text { electrical energy } \\
\text { consumption ex- } \\
\text { cluding the HPP } \\
\text { share }\end{array}$ & $\mathbf{4 0 5 6}$ & $\mathbf{4 2 2 6}$ & $\mathbf{4 4 2 3}$ & $\mathbf{4 6 2 9}$ & $\mathbf{4 8 4 3}$ \\
\hline $\begin{array}{l}\text { Electrical energy } \\
\text { import }\end{array}$ & 1095 & 1141 & 1194 & 1250 & 1308 \\
\hline $\begin{array}{l}\text { Total demand of CHP } \\
\text { electrical energy }\end{array}$ & 2961 & 3085 & 3229 & 3379 & 3535 \\
\hline $\begin{array}{l}\text { Total production of } \\
\text { CHP electrical energy }\end{array}$ & 2961 & 3085 & 3229 & 3379 & 3535 \\
\hline
\end{tabular}

It can be observed in Table 2 that in the base scenario both increase in electrical energy import, and production is visible. The ratio of import and internal production will remain unchanged. It means that the increase in demand will benefit both foreign and local producers. In this scenario, the internal pro- duction of electrical energy will always coincide with its demand, meaning that the internal producers possess sufficient capacity for meeting the demand.

In the base scenario, the market will remain in a state of status quo. The aim of the model is to determine a situation or situations, in which the Latvia companies of the energy sector will increase their competitiveness. For this purpose several series of modelling are carried out. The main of them are: determining the impact of fixed costs (amortization norms) on the competitiveness; the impact of primary energy resources (natural gas) price and the influence of complex factors on competitiveness. Below are shown the results of these experiments.

\subsection{The impact of depreciation on competitiveness}

In classical SPOT market, e.g. in Nord Pool, the market prices of electrical energy cover only the variable costs for the producers. In these conditions the fixed costs are not covered.

In the model, the fixed costs are connected with the amortization norm. According to the amortization norm, depreciation of equipment takes place, fixed assets are renewed, as well as these costs increase the potential price of the producers. In the base scenario, amortization norm of $4 \%$ per year is assumed. In the modelling scenario, the norm is reduced twice, and its performance results are shown in Figure 8.

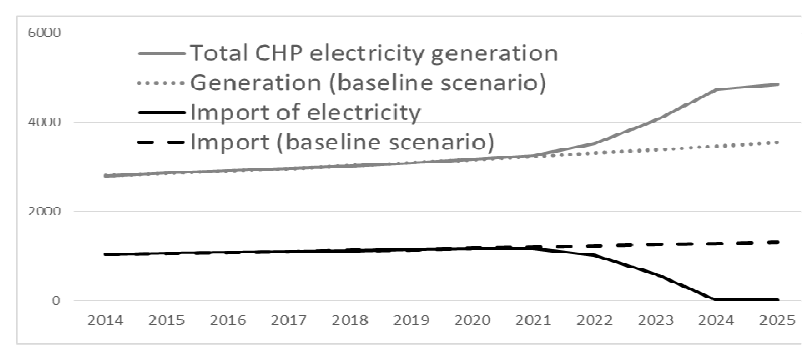

Fig. 8. Replacement of electrical energy import in the analysed scenario (GWh) (Source: Author)

Fig. 8 shows the comparison of the base scenario with the scenario of a decreased amortization norm. In the base scenario, the increase in import and production is close to linear increase trend, but in the analysed scenario production shall replace import. Up to year 2020 development is similar in both scenarios, however after year 2020 the production volumes will increase, and, accordingly, import volumes will decrease, if not renewal of fixed assets is carried out.

It is assumed in the model that the electrical energy market price will increase gradually, whereas the potential CHP electrical energy pro- 
duction price is the indicator to be modelled. The dynamics of changes in production prices are complex. Up to year 2021, while the energy production is close to a linear trend, the production costs and price decreases gradually. It is connected with the gradual decrease in means of production and their cost of upkeep. In this scenario, renewal of fixed assets will happen slower than their depreciation.

After year 2021 in the scenario, an increase in production is forecasted that will lead to additional depreciation of the fixed assets. As a result, the upkeep sums of the remaining fixed assets will decrease, leading to potential decrease in production price.

It is important to understand what is happening with the fixed assets of the sector during this period of time.

In the analysed scenario the volume of fixed assets decreases linearly up to year 2022. Further, up to year 2025, an increase is formed. This situation might suggest that the currently set capacity in the country is excessive (from the point of view of the current production), however, later when the production volumes increase and a part of the fixed assets are outworn, and the volume of the fixed assets could become closer to a balanced level.

With lower amortization norm and lower replacement costs, import volumes will replaced by internal production. With faster increase in production volumes, the volume of fixed assets will decrease with a higher intensity. The decrease in fixed assets is a fixed minimum. After this minimum is reached, the volume of the fixed assets will remain balanced, and further on, if demand for energy production increases, simultaneous increase in the volume of fixed assets will take place. It is important to note that with a low level of amortization the volume of the fixed assets will not decrease significantly. Its decrease will be stopped by the demand for capacity because, if electricity prices are low, the production capacity is loaded, and it is beneficial to restore it.

\subsection{Impact of primary resources (natural gas) price on competitiveness}

Together with the fixed costs, the competitiveness of electrical energy is significantly affected by the variable costs. The main component of the variable costs is the cost of natural gas.

The impact of natural gas price on the development of the sector is determined.

The research contains a simulation on the condition that the initial price of natural gas decreases by $30-40 \%$ (i.e., the price must be $160-190$ EUR/t.m³).
It is concluded that immediate decrease in the price of natural gas (and the rest of the primary resources) will not immediately increase the competitiveness of the sector, however in a long-term period it could result in increase in competitiveness and replacement of import with internal production. The reasons for it are the following: the price decrease of resources at the reflected level will not be sufficient enough for making it possible to immediately decrease the potential CHP electrical energy production price to the level corresponding with that of the market. However, further on the market price will gradually increase, and the potential CHP price will remain more competitive, resulting in the replacement of import (this situation is not forecasted in the base scenario).

\subsection{Impact of electrical energy market price on competitiveness}

Together with the production factors, competitiveness is affected by the market, its conjuncture, and, more importantly - price level. In this group of scenarios the impact of electrical energy market price on the competitiveness of the sector is analysed.

With the higher the market prices, the higher the difference between the production costs and market price, competitiveness is higher. In the base scenario, the increase in the price of electrical energy is $3 \%$ per year, but this group of experiments reflects the market reaction on the condition that prices increase by $4 \%$ per year. The results indicate that, over a long-term period, up to year 2024, the increase in price will not affect the competitiveness of the sector. The results will remain unchanged compared to the base scenario. After year 2024 the import of electrical energy will decrease.

It is justifiable with included relationships and actual data of the sector. Market prices increase in the analysed experiment, and up to year 2024 they are on the same level with the production costs. Further on, based on the increase in market price, the production costs will be lower than the market price. As a result, internal production could replace import; the sector will become more competitive.

\subsection{Complex facilitation of the competitiveness of the sector}

The previously conducted experiments show the impact of individual factors on the competitiveness of the sector. In the real world individual impact of factors almost does not occur. The factors make up the final result through interaction. In this group of experiments it is assumed that the amortization norm is reduced to $2 \%$ per year, and simultaneously 
the initial price of natural gas will decrease by 30 $40 \%$, and the market price of electrical energy will increase each year by $4 \%$. The results of the experiments are shown in Figure 9.

Having analysed the results, it can be observed in Figure 9 that with the conditions reflected above and in particularly favourable conditions the sector could become competitive in a very short period of time. The impact of all three factors could start to become visible in year 2016, by reducing the import to zero by year 2019 .

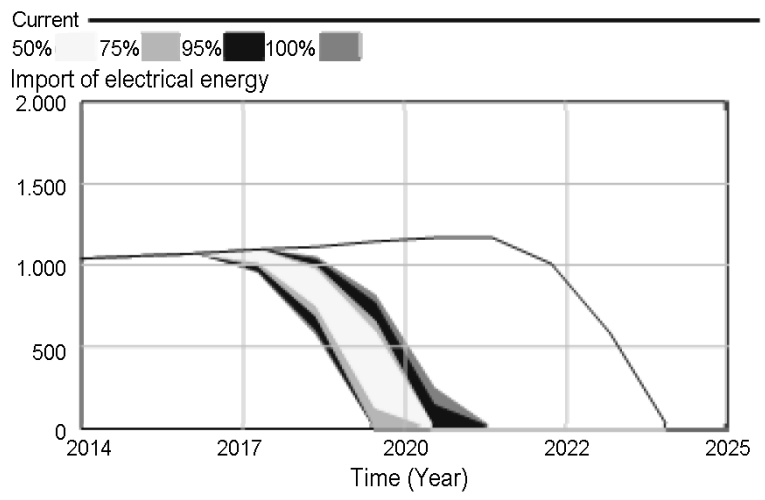

Fig. 9. Complex impact of factors on the import of electrical energy (Source: Authors)

\section{Conclusions}

By developing models through simulations, it is forecasted that consumption of electrical energy will slightly increase in all sectors. Energy losses will decrease up to year 2018 due to increase in efficiency, but further on they will increase in accordance with the overall tendencies of energy consumption. Both foreign and local producers will benefit from the increase in consumption.

Having evaluated the impact of factors on the competitiveness of the sector, it has been concluded that:

- Only the fixed costs must be taken into consideration when determining prices in the production of electrical energy in order to replace import and develop export.

They will result in both negative and positive consequences. One of the negative consequences would be decrease in fixed assets over a short period of time and consequent decrease in energetic safety. Renewal of fixed assets requires the use of financing outside the electrical energy market payments for energetic safety (for the installed capacity), as well as for the possible operation of CHPs in the heating energy market. With increasing demand for electrical energy, production of electrical energy will become more efficient due to the increasing scale, and it will make it possible to cover also the depreciation of the fixed assets. Hence, short-term determination of prices at the level of variable costs will develop the electrical energy sector. As a result, it could become competitive in the international market.

With a significant decrease in variable costs (costs of natural gas and other resources, or decrease in consumption), it is possible to increase the competitiveness of the sector in a long-term perspective. It could be achieved in several ways, starting from external (decrease in the price of resources), but, more importantly - internal (increase in efficiency).

The results of electrical energy market price simulation could lead to extensive discussions; how justified is the assumption of a $4 \%$ price increase per year, and is it possible at all? The aspect of price forecasting is one of the most complex aspects in the sector. Price deviations are extensive, for example, in January 2016 the market price ranged from 30 to $200 \mathrm{EUR} / \mathrm{MWh}$ (Nord Pool 2016). However, it confirms that there are conditions, in which increase in prices could enhance the competitiveness of the sector. The developed model reflects such conditions.

The complex impact reflects and intensifies the impact of individual factors. Decrease in amortization norm and decrease in natural gas price results in a decrease of production self-cost that, together with an accelerated increase in price, will significantly improve the competitiveness of the sector.

The developed model makes it possible to quickly and efficiently determine the possible ways of increasing the competitiveness of the sector.

\section{Funding}

This work was supported by the National Research Program 5.2. "Economic Transformation, Smart Growth, Governance and Legal Framework for the State and Society for Sustainable Development - a New Approach to the Creation of a Sustainable Learning Community [VPP EKOSOC-LV 5.2.1.].

\section{Disclosure statement}

Authors declare they don't have any competing financial, professional, or personal interests from other parties.

\section{References}

van Beeck, N. M. J. P. 1999. Classification of energy models, FEW Research Memorandum [online], [cited 29 January 2016]. Available from Internet: https://pure.uvt.nl/portal/files/532108/777.pdf 
Groscurth, H. M.; Kümmel, R. 1989. The cost of energy optimization: a thermoeconomic analysis of national energy system, Energy 14: 685-696. http://dx.doi.org/10.1016/0360-5442(89)90002-9

Grubb, M.; Edmonds, J.; Ten Brink, P.; Morrison, M. 1993. The costs of limiting fossil - fuel $\mathrm{CO}_{2}$ emissions: a survey and analysis, Annual Review of Energy and the Environment 18(1): 397-478.

http://dx.doi.org/10.1146/annurev.eg.18.110193.002145

Herbst, A.; Toro, F.; Reitze, F.; Jochem, E. 2012. Introduction to energy systems modelling, Swiss Journal of Economics and Statistics 148(2): 111-135.

Huang, G. H.; Baetz, B. W.; Patry, G. G. 1995. Grey integer pogramming: an application to waste management planning under uncertainty, European Journal of Operational Research 83: 594-620. http://dx.doi.org/10.1016/0377-2217(94)00093-R

Hudenko, J.; Počs, R. 2015. The discrepancy between the service export incomes of rail and sea transport among baltic states transit corridors, in $19^{\text {th }}$ World Multi-Conference on Systemics, Cybernetics and Informatics, 12-15 July 2015, Orlando, USA.

Kagan, N.; Adams, R. N. 1994. Electrical power distribution systems planning using fuzzy mathematical programming, International Journal of Electrical Power \& Energy Systems 16: 191-196. http://dx.doi.org/10.1016/0142-0615(94)90009-4

Kavrakoğlu, I. 1980. Decision analysis in the energy sector, Applied Mathematical Modelling 4: 456-462. http://dx.doi.org/10.1016/0307-904X(80)90178-X

Kélouwani, S.; Agbossou, K.; Chahine, R. 2005. Model for energy conversion in renewable energy system with hydrogen storage, Journal of Power Sources 140: 392-399. http://dx.doi.org/10.1016/j.jpowsour.2004.08.019

Kremers, E. 2013. Modelling and simulation of electrical energy systems through a complex systems approach using agent - based models [online], [cited 29 January 2016]. Available from Internet: www.ksp.kit.edu/download/1000031133

Lapiṇa, I.; Aramina, D.; Kairiša, I. 2015. Influence of organizational culture on the continuous improvement: empirical study at university, in $19^{\text {th }}$ World Multi-Conference on Systemics, Cybernetics and Informatics, 12-15 July 2015, Orlando, USA.

Martins, A. G.; Coelho, D.; Antunes, C. H.; Clímaco, J. 1996. A multiple objective linear programming approach to power generation planning with demand - side management (DSM), International Transactions in Operational Research 3: 305-317.

Nathani, C. 2006. Material use and induced energy demand: an input-output analysis, ETH Zürich, in the Intermediate International Input - Output Meeting on Sustainability, Trade and Productivity, 2006, Japan.

Nord Pool. 2016. [Online], [cited 29 January 2016]. Available from Internet: http://www.nordpoolspot.com/\#lv

Ozolina, V.; Počs, R. 2013. Macroeconomic modelling and elaboration of the macro - econometric model for the Latvian economy: scientific monograph. Riga: Riga Technical University.

Latvenergo. 1999. PVAS Latvenergo "Attīstības programma lìdz 2010 gadam”. PVAS Latvenergo, Rīga, Latvia.

Reḳis, J. 2014. Ekspertīze par galveno plānoto pasākumu Energ̊êtikas attīstības pamatnostādnēs 2014.2020. gadam ietekmi, Rīga.

Sadeghi, M.; Hosseini, H. M. 2006. Energy supply planning in Iran by using fuzzy linear programming approach (regarding uncertainties of investment costs), Energy Policy 34: 993-1003. http://dx.doi.org/10.1016/j.enpol.2004.09.005

Schade, W.; Jochem, E.; Barker, T.; Catenazzi, G.; Eichhammer, W.; Fleiter, T. 2009. ADAM-2 degree scenario for Europe - policies and impacts. Deliverable M1.3 of ADAM (Adaptation and mitigation strategies: supporting european climate policy). Karlsruhe, Germany.

Schrattenholzer, L. 1981. The energy supply model MESSAGE [online], [cited 29 January 2016]. Available from Internet: http://webarchive.iiasa. ac.at/Admin/PUB/Documents/RR-81-031.pdf

Schulz, V.; Stehfest, H. 1984. Regional energy supply optimization with multiple objectives, European Journal of Operational Research 17: 302-312. http://dx.doi.org/10.1016/0377-2217(84)90124-3

Skribans, V. 2010. Latvijas energosektora sistēmdinamikas prognozēšanas modeḷa izstrāde, Enerǵētika un elektrotehnika 26: 34-40.

Timilsina, R. G. 2011. Sectoral models for energy and climate policies [online], [cited 29 January 2016]. Available from Internet: http://web.worldbank. org/archive/website01354/WEB/IMAGES/GG_EN ERG.PDF

Tuvikene, L.; Bogdanova, O.; Skribans, V. 2015 regional cooperation optimization model: addressing energy challenges in the baltic sea region, Eastern European Business and Economics Journal 1(1): 2-11.

Wallace, S. W.; Fleten, S. E. 2003. Stochastic programming models in energy, in Handbooks in $O R$ \& $M S$. Elsevier.

Wien Automatic System Planning (WASP) Package; User's Manual. 2001 [online], [cited 29 January 2016]. Available from Internet: http://www.pub. iaea.org/MTCD/publications/PDF/CMS-16.pdf

Yeh, S. C. 1995. Application of grey programming to water resources management. School of Civil and Environmental Engineering, Cornell University: Ithaca, NY, USA.

Zeng, Y.; Cai, Y.; Huang, G.; Dai, J. 2011. A review on optimization modeling of energy systems planning and ghg emission mitigation under uncertainty, Engineering and Policy Journal 4: 1624-1656 [online], [cited 29 January 2016]. Available from Internet: www.mdpi.com/1996-1073/4/10/1624/pdf

Zeps, A.; Ribickis, L. 2014. Strategy development process in higher education institutions, in 8th International Scientific Conference "Business and Management 2014”, 15-16 May 2014, Vilnius, Lithuania. 